\title{
Analisis Volume Modal Kerja dan Fluktuasi Laba pada Usaha Dagang Pisang Agung Lumajang
}

\author{
Istichomah \\ Program Studi Manajemen, STIE Widya Gama Lumajang \\ isistiqomah4828@gmail.com
}

\begin{abstract}
Abstrak
Penelitian ini digunakan, agar pemilik usaha bisa mengetahui perkembangan volume modal kerja dan fluktuasi tingkat laba pada perusahaan. Studi kasus dilakukan di pengelolaan kayu pada UD. Pisang Agung Lumajang. Pengujian ini dilakukan terhadap keadaan keuangan yang berlangsung selama tiga tahun dari tahun 2015 sampai tahun 2017 dan penelitian ini tidak lain ingin mengetahui volume modal kerja dan fluktuasi tingkat laba dengan menggunakan rumus-rumus yang sudah ada untuk menganalisisnya. Hasil penelitian menunjukkan bahwa pada tahun 2015 yang diawali dengan modal sebesar Rp 525.000.000,00 yang kemudian mengalami penurunan pada tahun selanjutnya yaitu 2016 menjadi Rp 482.000.000,00 dan mengalami kenaikan yang cukup signifikan pada tahun berikutnya 2017 sehingga menjadi Rp 630.000.000,00. Untuk perkembangan tingkat laba pada tahun 2015, laba kotor sebesar Rp 210.000.000,00 dengan penjualan Rp 1.152.0145.000,00 dengan tingkat prosentase sebesar $18.21 \%$ pada tahun selanjutnya 2016 laba kotor sebesar Rp 225.000.000,00 dengan penjualan Rp 1.254.260.000,00 dengan tingkat prosentase $17.93 \%$ hasil tersebut menunjukkan adanya penurunan diperiode tersebut, pada tahun berikutnya tahun 2017 laba kotor sebesar Rp 235.000.000,00 artinya mengalami peningkatan dengan penjualan sebesar $\mathrm{Rp}$ 1.275.358.000,00 dengan prosentase sebesar 18.42\%. Berdasarkan hasil analisa bahwa, modal kerja merupakan unsur yang berperan dalam menghasilkan pendapatan,sedangkan laba dapat menentukan tingkat prestasi perusahaan. Kenaikan angka penjualan tidak selalu menaikkan tingkat laba yang diterima perusahaan. Untuk itu pihak manajemen harus memastikan tingkat efektifitas dan efisiensi perusahaan berbanding lurus dengan penjualan perusahaan karena penjualan perusahaan tidak selalu menaikkan tingkat laba perusahaan di tahun yang sama. Peneliti berharap untuk penelitian selanjutnya agar memperluas atau mengembambangkan penelitian tersebut dengan menambahkan faktor lain yang mempengaruhi volume modal kerja dan fluktuasi tingkat laba.
\end{abstract}

\section{Kata kunci : Modal Kerja, Tingkat Laba, Penjualan}

\section{Abstract}

This research is used, so that business owners can find out the development of the volume of working capital and fluctuations in the level of profits in the company. Case studies carried out in wood management at UD. Agung Lumajang Banana. This test is carried out on the financial situation that lasted for three years from 2015 to 2017 and this study no other wants to know the volume of working capital and fluctuations in the level of profit using existing formulas to analyze it. The results showed that in 2015 it began with a capital of IDR 525,000,000.00 which then decreased in the following year namely 2016 to IDR 482,000,000.00 and experienced a significant increase in the following year 2017 to IDR 630,000,000, 00. For the development of profit levels in 2015, gross profit of IDR 210,000,000.00 with sales of IDR 1,152,0145,000.00 with a percentage rate of 18.21\% in the following year 2016 gross profit of IDR 225,000,000.00 with sales of IDR 1,254,260,000, 00 with a percentage level of 17.93\%, the results indicate a decrease in that period, 
in the following year 2017 gross profit of IDR 235,000,000.00 means experiencing an increase in sales of IDR 1,275,358,000.00 with a percentage of 18.42\%. Based on the results of the analysis that, working capital is an element that plays a role in generating income, while profit can determine the level of achievement of the company. The increase in sales figures does not always increase the level of profits received by the company. For this reason, the management must ensure that the level of effectiveness and efficiency of the company is directly proportional to the company's sales because the sales of the company do not always increase the level of corporate profits in the same year. Researchers hope for further research to expand or describe the research by adding other factors that affect the volume of working capital and fluctuations in the level of profits.

\section{Keywords: Working Capital, Rate Of Profit, Sales}

\section{PENDAHULUAN}

Modal kerja merupakan masalah pokok dan topik penting yang sering kali dihadapi oleh perusahaan, karena modal kerja dibutuhkan oleh setiap perusahaan untuk membiayai operasinya sehari-hari, misalnya untuk memberikan persekot pembelian bahan mentah, membiayai upah gaji pegawai dan lain-lain, dimana uang atau dana yang dikeluarkan tersebut diharapkan dapat kembali lagi masuk dalam perusahaan dalam waktu singkat melalui hasil penjualan produksinya. Oleh karena itu, perusahaan dituntut untuk selalu meningkatkan efisiensi kerjanya sehingga dicapai tujuan yang diharapkan oleh perusahaan yaitu mencapai laba yang optimal. Laba merupakan indikator yang dapat digunakan untuk mengukur kinerja operasional perusahaan. Informasi tentang laba mengukur keberhasilan atau kegagalan bisnis dalam mencapai tujuan operasi yang ditetapkan (Parawiyati, 1996).

Informasi tentang laba (earnings) mempunyai peran sangat penting bagi pihak yang berkepentingan terhadap suatu perusahaan. Pihak internal dan eksternal perusahaan sering menggunakan laba sebagai dasar pengambilan keputusan seperti pemberian kompensasi dan pembagian bonus kepada manajer, pengukur prestasi atau kinerja manajemen, dan dasar penentuan besarnya pengenaan pajak.Oleh karena itu kualitas laba menjadi pusat perhatian bagi investor, kreditor, pembuat kebijakan akuntansi, dan pemerintah. Laba yang berkualitas adalah laba yang dapat mencerminkan kelanjutan laba (sustainable earnings) dimasa depan, yang ditentukan oleh yang salah satunya ditentukanoleh modal kerja (Penman, 2011:323).

Pada umumnya perusahaan harus dapat mempertahankan jumlah aktiva lancar yang lebih besar dibanding hutang lancarnya, hal ini agar perusahaan mempunyai kemampuan untuk membayar kebutuhan-kebutuhan jangka pendeknya. Akan tetapi dalam hubungan dengan fungsi modal kerja dalam menghasilkan pendapatan, maka perhatian selanjutnya akan terfokus pada masalah penggunaan dana atau alokasi dana daripada mendapatkan dana. Aktiva lancar umumnya terdiri dari kas, efek, piutang dagang, persediaan barang dan sebagainya. Apabila tidak tepat dalam pengelolaannya akan mempengaruhi kelangsungan hidup perusahaan.

Peneliti tertarik untuk melakukan penelitian tentang analisis pengelolaan modal kerja, karena dengan alasan mendasar bahwa analisis pengelolaan modal kerja sangat penting dilakukan di dalam perusahaan, baik perusahaan swasta maupun perusahaan pemerintah atau instansi yang bernaung dibawah pemerintah. Dengan menganalisis pengelolaan modal kerja, maka dapat diketahui kemampuan perusahaan dalam mengelolah modal kerja agar mendapatkan laba atau keuntungan yang setinggi-tingginya. Berdasarkan uraian latar belakang diatas, maka batasan masalah dalam 
penelitian ini adalah analisis volume modal kerja dan fluktuasi tingkat laba pada UD. Pisang Agung Lumajang. Dengan perumusan masalah dalam penelitian ini adalah bagaimana perkembangan volume modal kerja pada UD. Pisang Agung Lumajang selama periode 2015-2017?. Bagaimana perkembangan fluktuasi tingkat laba pada UD. Pisang Agung Lumajang periode 2015-2017?.

\section{METODE PENELITIAN}

Penelitian yang digunakan yaitu metode deskriptif, karena penelitian yang disusun dalam rangka memberikan gambaran secara sistematis tentang informasi ilmiah yang berasal dari subjek atau objek penelitian (Sanusi, 2011:13). Sehingga peneliti dapat memfokuskan pada jenis penelitian studi kasus. Dengan metodologi penelitian kualitatif dan kuantitatif (Narimawati, 2008). Studi kasus ini merupakan jenis penelitian yang rinci mengenai suatu obyek tertentu selama kurun waktu tertentu dengan cukup mendalam dan menyeluruh. Hal ini berkaitan dengan data yang digunakan peneiliti untuk melengkapi penelitiannya, yaitu menggunakan laporan keuangan, tingkat kinerja keungan dan perkembangan laba perdagangan sehingga penelitian ini menjadi lebih terperinci.

Sumber data yang digunakan dalam penelitian ini berupa data internal, diperoleh dari UD. Pisang Agung Lumajang, berupa profil , dasar hukum pendirian dan laporan keuangan. Jenis data yang digunakan dalam penelitian ini adalah data sekunder, yang diperoleh dari hasil observasi padaUD. Pisang Agung Lumajang yang menjadi obyek penelitian dalam penelitian ini. Teknik pengumpulan data dengan menggunakan beberapa teknik yaitu dokumentasi merupakan pengumpulan data dengan menggunakan dokumen-dokumen, buku atau arsip yang ada di perusahaan yang dikaitkan dengan penelitian yaitu laporan keuangan UD. Pisang Agung Lumajang menjadi obyek dalam penelitian ini untuk periode 2015-2017. Laporan keuangan yang digunakan adalah laporan neraca dan laporan rugi laba. Serta observasi yaitu mengadakan tinjauan secara langsung terhadap objek penelitian dengan cara mengamati, meneliti dan mempelajari tentang data-data sekunder yang didapat peneliti.

Variabel penelitian dengan Identifikasi variabel guna menentukan variabel-variabel yaitu variabel pengelolaan modal kerja terhadap tingkat laba dengan menggunakan analisis dalam menentukan pembahasan penelitian. Dalam penelitian ini terdapat dua jenis variabel yang digunakan, yaitu Menurut Harahap (2004:288) mengemukakan bahwa modal kerja merupakan unsur yang berperan dalam menghasilkan pendapatan. Ketidaktepatan dalam menentukan jumlah modal kerja yang dibutuhkan akan mengakibatkan kegiatan perusahaan terganggu, dan bila hal ini berlangsung terus menerus akan mempengaruhi kelangsungan perusahaan. Dengan demikian pengelolaan aktiva lancar melalui perkembangan modal kerja merupakan salah satu aspek penting yang dibutuhkan oleh suatu perusahaan. Penerapan modal kerja yang tepat akan lebih mendorong pencapaian pertumbuhan dan perluasan kegiatan perusahaan. Untuk mengukur perkembangan modal kerja dapat dilakukan dengan menghitung aktiva lancar dikurangi dengan utang lancar dengan menggunakan skala persentase (Hanafi, 2009:39-42).

Rumus peghitungan perkembangan modal kerja menggunakan aktiva lancar dikurangi utang lancar. Kegunaan laba yaitu untuk menentukan prestasi perusahaan sebagai informasi bagi pembagian laba dan penentukan kebijakan investasi. Oleh karena itu, laba menjadi informasi yang dilihat oleh banyak seperti profesi akuntansi, pengusaha, analis keuangan, pemegang saham, ekonomi, fiskus, dan sebagainya (Harahap, 2006:26). Untuk mengukur tingkat perkembangan laba dapat diketahui dengan penghitungan laba kotor dibagi penjualan. 
Dalam penelitian ini menggunakan metode diskriptif yang berupa studi kasus, yaitu jenis penelitian yang terperinci mengenai suatu objek tertentu selama kurun waktu tertentu, termasuk ligkungan dan kondisi masa lalunya, dengan cukup mendalam dan menyeluruh.

Data yang akan dianalisis adalah data yang tersedia di laporan neraca dan laporan laba rugi yang akan digunakan untuk menghitung tingkat laba perusahaan dalam satu periode.

\section{HASIL DAN PEMBAHASAN}

Pada awalnya tempat ini merupakan gudang kayu yang pada akhirnya berubah menjadi Usaha Dagang, UD. Pisang Agung Lumajang sebagai salah satu perusahaan yang sedang berkembang. Salah satu kegiatan UD.Pisang Agung Lumajang adalah menjual hasil produksi olahan kayu gelondong berupa tempat barang-barang sembako atau sering disebut keplekan. Lokasi UD. Pisang Agung Lumajang berada di desa Kunir Kecamatan Tempeh, Kabupaten Lumajang. Perusahaan ini mulai berdiri pada tahun 2014 di bidang penggergajian kayu gelondongan, yang di proses untuk dijadikan balken dan dikirim ke beberapa pembeli untuk di proses lebih lanjut. Modal awal perusahaan sebesar Rp 100.000.000,00 dan pada tahun 2015 modal kerja perusahaan berkembang mencapai Rp 120.000.000,00 dan menghasilkan laba kotor sebesar Rp 227.000.000,00 di tahun yang sama.

Perkembangan modal kerja yang dihitung dengan membandingkan antara aktiva lancar dengan hutang lancar untuk tahun 2015-2017 dari data laporan keuangannya yaitu neraca UD.Pisang Agung Lumajang tahun 2015-2017. Jumlah modal kerja tahun 2015, aktiva lancar dikurangi utang lancar atau $\mathrm{Rp}$ 525.000.000,00 dikurangi Rp 60.000.000,00 sebesar Rp 465.000.000,00, tahun 2016 aktiva lancar dikurangi utang lancar atau Rp 482.000.000,00 dikurangi Rp 50.000.000,00 sebesar $\mathrm{Rp}$ 432.000.000,00, tahun 2017 aktiva lancar dikurangi utang lancar atau $\mathrm{Rp}$ 630.000.000,00 dikurangi Rp 80.000.000,00 sebesar Rp 550.000.000,00

Dapat diketahui bahwa modal kerja pada tahun 2015 sebesar Rp 465.000.000,00 dan mengalami penurunan pada tahun 2016 yaitu Rp 432.000.000,00 dan pada tahun 2017 mengalami kenaikan yaitu Rp 550.000.000,00. Penurunan hutang lancar sebesar Rp10.000.000,00 pada tahun 2016 tidak membuat modal kerja pada tahun 2016 naik, hal ini disebabkan oleh turunnya aktiva lancar sebesar Rp 43.000.000,00 pada tahun 2016 jika dibandingkan dengan aktiva lancar pada tahun 2015. Sedangkan pada tahun 2017 kenaikan modal kerja disebabkan oleh kenaikan aktiva lancar sebesar Rp 148.000.000,00 meskipun terdapat kenaikan hutang lancar sebesar Rp 30.000.000,00 pada tahun 2017 jika dibandingkan hutang lancar pada tahun 2016. Jadi dapat disimpulkan modal kerja mengalami grafik fluktuatif selama periode 2015-2017. Perkembangan tingkat laba yang dihitung dengan membandingkan antara laba kotor dengan penjualan untuk tahun 2015 - 2017 dari data laporan keuanganyaitu laporan keuangan laba rugi UD.Pisang Agung Lumajang tahun 2015-2017, yaitu:

Tabel 1. Tingkat Laba menggunakan rasio Gross Profit Margin (GPM)

\begin{tabular}{ccc}
\hline Tahun & Instrumen & Hasil \\
\hline \multirow{2}{*}{2015} & $\frac{\text { Laba Kotor }}{\text { Penjualan }} \times 100 \%$ & $\frac{210.000 .000}{1.153 .045 .000} \times 100=18,21 \%$ \\
2016 & $\frac{\text { Laba Kotor }}{\text { Penjualan }} \times 100 \%$ & $\frac{225.000 .000}{1.254 .260 .000} \times 100 \%=17,93 \%$ \\
2017 & $\frac{\text { Laba Kotor }}{\text { Penjualan }} \times 100 \%$ & $\frac{235.000 .000}{1.275 .358 .000} \times 100=18,42 \%$ \\
\hline
\end{tabular}


Persentase tingkat laba pada tahun 2015 sebesar 18,21\%, sedangkan pada tahun 2016 mengalami penurunan sebesar $0,28 \%$ jika dibandingkan tingkat laba pada tahun 2015, adapun tingkat laba pada tahun 2016 yakni 17,93\%, penurunan tingkat laba tahun 2016 disebabkan oleh kenaikan penjualan namun tidak di imbangi oleh kenaikan laba kotor yang tidak begitu signifikan.Pada tahun 2017 tingkat laba mengalami peningkatan $0.49 \%$ jika dibandingkan pada tahun 2016, persentase laba pada tahun 2017 yakni 18,42\%.

Berdasarkan hasil analisis dapat dilihat bahwa, modal kerja merupakan unsur yang berperan dalam menghasilkan pendapatan,sedangkan laba dapat menentukan tingkat prestasi perusahaan. Dalam hal ini, berdasarkan hasil yang diperoleh sejalan dengan teori yang melandasi sama halnya dengan penelitian terdahulu (Dewi : 2003). Dimana modal kerja tersebut mempengaruhi tingkat laba yang diperoleh oleh perusahaan tersebut atau berbanding lurus. Jika dilihat analisa hasil analisa diatas, dapat diketahui bahwa modal kerja dari setiap tahun 2015 - 2017,mengalami kenaikan dan penurunan setiap tahunnya,modal kerja pada tahun 2015, dan mengalami penurunan pada tahun 2016, Penurunan hutang lancar pada tahun 2016 tidak membuat modal kerja pada tahun 2016 naik, hal ini disebabkan oleh turunnya aktiva lancar sebesar pada tahun 2016 jika dibandingkan dengan aktiva lancar pada tahun 2015 .

Sama halnya dengan tingkat laba perusahaan tersebut juga mengalami kenaikan dan penurunan setiap tahunnya.Persentase tingkat laba pada tahun 2015 sebesar 18,21\%, sedangkan pada tahun 2016 mengalami penurunan sebesar 0,28 persen jika dibandingkan tingkat laba pada tahun 2015, adapun tingkat laba pada tahun 2016 yakni 17,93\%, penurunan tingkat laba tahun 2016 disebabkan oleh kenaikan penjualan namun tidak di imbangi oleh kenaikan laba kotor yang tidak begitu signifikan. Hal tersebut manggambarkan tingkat efektifitas kenaikan penjualan tidak seimbang dengan laba kotor yang diterima perusahaan.

Sedangkan pada tahun 2017 tingkat laba mengalami peningkatan 0.49\% jika dibandingkan pada tahun 2016, persentase laba pada tahun 2017 yakni 18,42\%. Tingkat laba tahun 2017 sebesar 18,42\% merupakan tingkat laba tertinggi selama tahun 2015-2017. Pada tahun 2017 faktor kenaikan tingkat laba disebabkan oleh penerimaan laba kotor lebih efektif dengan kenaikan angka penjualandengan kenaikan laba kotor sebesar $47 \%$ prosentase antara kenaikan laba kotor dengan kenaikan penambahan angka penjualan. Secara umum hal tersebut manggambarkan bahwa peningkatan angka penjualan tidak selalu memberikan penambahan tingkat prosentase laba perusahaan.

Hal tersebut sesuai dengan penelitian yang dilakukan oleh Maria ulfa (2004) bahwa Faktor yang menyebabkan kenaikan tingkat rentabilitas ekonomi ialah penjualan meningkat, sedangkan faktor yang menyebabkan penurunan tingkat rentabilitas ekonomi yaitu penjualan menurun, harga pokok penjualan meningkat, biaya-biaya meningkat. Hasil analisis yang telah dilakukan maria, menyimpulkan bahwa modal kerja berpengaruh terhadap tingkat rentabilitas ekonomi pada PT. Abadi Mukti Kirana Property Kota bandung, tetapi pengaruhnya sangatlah kecil yaitu sebesar 4,5\%. Analisis modal kerja pengaruhnya terhadap tingkat rentabilitas ekonomi mempunyai hubungan positif atau searah antara modal kerja terhadap tingkat rentabilitas ekonomi.Tingkat kerentanan antara Modal Kerja dan Tingkat Rentabilitas Ekonomi merupakan hubungan yang rendah dan searah. 


\section{KESIMPULAN}

Dari pembahasan penelitian diatas maka dapat disimpulkan bahwa perusahaan ini, UD. Pisang Agung Lumajang awalnya merupakan perusahaan yang berupa gudang kayu yang pada akhirnya berubah menjadi Usaha Dagang, Perusahaan ini menjual hasil produksi olahan kayu gelondong berupa tempat barang-barang sembako atau sering disebut keplekan.Selama berproduksi perusahaan sudah mempunyai tujuan agar dapat mengelola modal kerja dengan baik.Bahan baku sudah banyak tersedia dari berbagai desa yang tidak jauh dari lokasi tempat industri dan mendatangkan kayu dari Kabupaten Jember dan Banyuwangi. UD.Pisang Agung Lumajang sekarang ini sudah mempunyai 5 (lima) mesin pengergaji kayu yang masing-masing mesin diperasikan oleh 3 (tiga) orang operator mesin. Berdasarkan hasil analisis diatas dapat dilihat bahwa, modal kerja merupakan unsur yang berperan dalam menghasilkan pendapatan,sedangkan laba dapat menentukan tingkat prestasi perusahaan. Dalam hal ini, berdasarkan hasil yang diperoleh sejalan dengan teori yang melandasi sama halnya dengan penelitian terdahulu (Dewi : 2003). Dimana modal kerja tersebut mempengaruhi tingkat laba yang diperoleh oleh perusahaan tersebut atau berbanding lurus.

Berdasarkan hasil dari penelitian ini terdapat saran-saran untuk perusahaan sebagai proyeksi kedepan diantarannya, suatu perusahaan harus benar - benar menghitung tingkat modal kerja terhadap tingkat laba dengan artian jangan sampai tingkat modal kerja lebih besar dari tingkat kebutuhan perusahaan, karena apabila tingkat modal kerja lebih besar dari biaya perusahaan, maka akan dapat menimbulkan kerugian perusahaan tersebut. Dengan demikian sudah semestinya perusahaan mendorong peningkatan kenaikan angka penjualan setiap tahunnya.

Perusahaan juga harus memperhatikan tingkat efektifitas dan efisiensi penggunaaan modal kerja. Kenaikan angka penjualan tidak selalu menaikkan tingkat laba yang diterima perusahaan. Untuk itu pihak manajemen harus memastikan tingkat efektifitas dan efisiensi perusahaan berbanding lurus dengan penjualan perusahaan karena penjualan perusahaan tidak selalu menaikkan tingkat laba perusahaan di tahun yang sama.

\section{DAFTAR PUSTAKA}

Halim, A. \& Hanafi, M. M. (2009). Analisis Laporan Keuangan. Edisi 4. Yogyakarta: UPP STIM YKPN.

Harahap, S. S. (2001). Analitis Kritis Atas Laporan Keuangan. Cetakan Ketiga. Jakarta: PT Rajagrafindo Persada.

Husnan, S. (2001). Dasar-Dasar Manajemen Keuangan Cetakan ke 2. Yogyakarta: Unit Penerbit dan Percetakan Akademi Perusahaan YKPN.

Kasmir. (2011). Analisis Laporan Keuangan. Jakarta : PT. Rajagrafindo Persada.

Keown, et al. (2010). Dasar-dasar Manajemen Keuangan, Buku Kedua, Edisi Pertama, Alih Bahasa Chaerul Djakman dan Sulistryatini. Jakarta : Salemba Empat.

Kieso, D. E., Weygandt, J. J., Warfield, T. D. (2002). Akuntansi Intermediete, Terjemahan Emil Salim, Jilid 1, Edisi Kesepuluh, Jakarta : Penerbit Erlangga.

Kuncoro, M. (2007). Metode Riset Untuk Bisnis dan Ekonomi, Jakarta : Erlangga.

Munawir, S. (2002). Analisis Laporan Keuangan, Edisi Kedua. Jogyakarta : YPKN.

Munawir, S. (2004). Analisis Laporan Keuangan. Yogyakarta : Liberty.

Narimawati, U. (2008). Metodologi Penelitian Kualitatif dan Kuantitatif, Teori dan Aplikasi. Bandung: Agung Media.

Parawiyati. (1996). Kemampuan Laba dan Arus Kas dalam Memprediksi Laba dan Arus Kas Perusahaan Go Publik di Pasar Modal. Tesis. S2 Program Pasca Sarjana UGM, Yogyakarta.

Penman, S. H. (2011). Financial Statement Analysis and Security Valuation. Singapore : Irwin McGraw-Hill. 
Prawirosentono, S. (2002). Pengantar Bisnis Modern, Studi Kasus dan Analisis Kuantitatif. Jakarta : Bumi Aksara.

Riyanto, B. (2001). Dasar-dasar Pembelanjaan Perusahaan, Edisi Keempat, Cetakan Ketujuh, Yogyakarta : Penerbit BPFE.

Riyanto, B. (2011). Dasar-Dasar Pembelanjaan Perusahaan. BPFE. Yogyakarta.

Sanusi, A. (2011). Metodologi Penelitian Bisnis. Jakarta: Salemba Empat

Sutrisno. (2009). Manajemen Keuangan Teori, Konsep dan Aplikasi, Edisi Pertama, Cetakan Ketujuh, Yogyakarta: Penerbit Ekonisia.

Syamsuddin, L. (2002). Manajemen Keuangan Perusahaan, Edisi Baru, Cetakan Ketujuh, Jakarta: PT Raja Grafindo Persada. 